This item was submitted to Loughborough's Research Repository by the author.

Items in Figshare are protected by copyright, with all rights reserved, unless otherwise indicated.

\title{
Sport as a critique of politics: Everest climbing, nationalism and the failure of politics in Bangladesh [Reply]
}

\section{PLEASE CITE THE PUBLISHED VERSION}

http://dx.doi.org/10.1080/23269995.2015.1021195

\section{PUBLISHER}

Taylor \& Francis (Routledge)

\section{VERSION}

AM (Accepted Manuscript)

\section{PUBLISHER STATEMENT}

This work is made available according to the conditions of the Creative Commons Attribution-NonCommercialNoDerivatives 4.0 International (CC BY-NC-ND 4.0) licence. Full details of this licence are available at: https://creativecommons.org/licenses/by-nc-nd/4.0/

\section{LICENCE}

CC BY-NC-ND 4.0

\section{REPOSITORY RECORD}

Bairner, Alan. 2019. "Sport as a Critique of Politics: Everest Climbing, Nationalism and the Failure of Politics in Bangladesh [reply]". figshare. https://hdl.handle.net/2134/19955. 


\title{
Sport as a Critique of Politics: Everest Climbing, Nationalism and the Failure of Politics in Bangladesh
}

\author{
Alan Bairner ${ }^{\mathrm{i}}$
}

According to Ahmed (2014: 266) it can be argued that 'in postcolonial contexts such as East Pakistan/Bangladesh a variety of cultural forms play specific roles in the imagining of the postcolonial nation, and that the most influential national forms may be those most accessible to the collective regardless of literacy such as poetry, music, song, and film'. One must surely add sport to this list.

That sport, national identity and nationalism are closely interwoven has become something of truism and one that is regularly rehearsed in academic literature on sport (Bairner, 2001, 2004; Cronin, 1999; Porter and Smith, 2004; Rowe, 2003). In reality, of course, whilst such a relationship almost certainly exists in every nation and nation-state in the world, what is arguably of much greater interest is the specificity of the relationship in particular societies. This mean disaggregating the terms nation state and nation and nationality and national identity as well as taking into account the differing forms that expressions of nationalism can take. This is especially so with reference to those countries which have received relatively little attention in this respect or where attention has tended to focus on certain sports rather than on sport and physical activity more generally. The latter is certainly true of Bangladesh.

In countless respects, therefore, Mubashar Hasan's article provides a valuable service. It opens upon the politics of Bangladesh to an international audience. It adds to our understanding of the ways in which politicians seek to manipulate the physical achievements of citizens for their own ends. Conversely, it also offers a plausible argument that 
Bangladesh's mountaineers have used the conquest of Everest in an altogether different way, namely to critique the political establishment of their country.

My reply to the article focusses on the three themes - first, nationalism in Bangladesh, second. the questions of whether or not mountaineering is a sport and how we can compare it in the Bangladesh context with cricket and, finally, whether any realistic hope of change is to found in the apparently subversive behaviour of the mountaineers.

Hasan's essay discusses the relationship between nationalism and Everest climbing within the context of the politics of Bangladesh. What emerges very clearly is the extent to which politicians have sought to harness the achievements of Bangladesh's climbers to the twin causes of national unity and international recognition. However, even within a single nation or a single nation state, readings of the nation are regularly contested. In the case of Bangladesh this would seem to me to necessitate a more extended explanation of the precise relationship between the political utilization of the mountaineers and the two main expressions of nationalism in Bangladesh, one legacy of which, as Hasan notes, has been the difficulty of finding non-controversial national heroes.

As Hossain and Khan (2006: 324) note, 'The debate over national identity, whether it should be Bengali [Bangali] or Bangladeshi, became a key political issue in post-1975 Bangladesh’. Nationalism unites but also divides. It would be interesting to know to which, if either, of these nationalisms the mountaineers subscribe - the former of which is rooted in ethnolinguistic and ethno-cultural characteristics and served to unite the inhabitants of Bengal or East Pakistan during the war of independence or the latter which was introduced initially by General Zia in an effort to link religion to national identity. As a consequence, the very identity of the nation itself became a major feature of the country's ideological divisions (Moniruzzaman, 2009). According to Hossain and Kahn (2006: 326), 'Bangali nationalism is 
a natural manifestation while Bangladeshi nationalism is an imposed one'. Yet based on their analysis of Bangladesh, they later conclude that that 'national consciousness is a politically determined concept' (p. 337). It is for that reason that we are entitled to ask whether or not different versions of nationalism are involved in the climbers' critique of politics.

It is doubtful of course if many people would associate Bangladesh with mountaineering at all. Indeed, as far as sport is concerned, cricket might seem to provide more fertile ground for an examination of nationalism in Bangladesh. Yet, even in that sport, there is contestation. As Bandyopadhyay 2013: 19) argues, 'Cricket in Bangladesh and Bangladeshi cricket are two different entities'. In the past, the nation was a hotbed of association football (Dimeo, 2001). However, since first East Pakistan and then Bangladesh itself came into existence, cricket has become a national obsession. Despite this, as Dasgupta (2007: 177) argues, 'Bangladesh cricket is at a crossroads'. Its players are out of their depth except when they play against Zimbabwe or associate members of the International Cricket Council. According to Bandyopadhyay (2013: 20), Bangladesh’s cricketing identity 'cuts across variegated political, social, economic, religious and professional affiliations'. That certainly addresses the contested nature of the nation. However, given limited international success, the sport may offer less leverage or soft power than the conquest of Everest to the political classes. This depends though on a number of factors.

How well known globally are the exploits of Bangladesh's mountaineers? Is what they do even a sport? And, finally, does the character of their activity allow more scope for expressions of personal political views than for manipulation by politicians with their particular understanding of what best serves the interests of the nation?

With the ascent of Everest becoming almost commonplace amongst elite mountaineers and even some with rather less experience, it is doubtful if the achievements of the climbers 
discussed in Hasan's paper have done much to put Bangladesh on the map. A win or two by the nation's cricketers against leading test-playing countries would surely attract considerably more global attention. Furthermore, as regards the relationship between sport and national identity, mountaineering's place in the discussion is far from unproblematic.

According to Bartlett (2013: 152), 'Mountaineering is an egocentric pursuit, an opportunity for the individual to assert himself or herself not only against nature but against other people'. But is it a sport? The intention to award medals to mountaineers can be traced back to the Olympic congress of 1894 and medals have been presented to climbers at regular intervals ever since. According to Bartlett (2013: 156), however, 'Olympic sport requires the mirror that is other people to make it meaningful. It is not just that winning the 100 metres is egocentric, but that it’s a public form of egocentricity. It needs an audience and preferably some other athletes'. For that reason, he concludes that 'Mountaineering is a sport, yes, but of a different hue to the Olympic variety. As the dictionary wisely suggests: amusement, diversion, fun’ (p. 157).

Activities such as climbing Everest, no matter how impressive, cannot compete with team sports in which the athletes perform as proxy warriors bedecked in the national colours and cheered on by adoring fans. On the other hand, the individualism of mountaineering is such that it acts as a buffer to simply being embraced by and/or embracing the nation regardless of its many failings. The climbers discussed in Hasan’s essay are demonstrably proud to have planted the Bangladesh flag at the summit of Mount Everest. But they are simultaneously ashamed that their country fares so badly according to a wide range of indices. Just as politicians seek to exploit their achievements, so they too seek to take advantage of their status as national heroes to point to the failure of politics in Bangladesh. Would that athletes who perform in more highly visible sports act in such a principled manner. But here is the crux of the problem. It is they - the cricketers, for example - rather than the mountaineers 
who can reach a bigger audience. In the meantime, the politicians are more able than either group to manipulate the media and thereby delay, or perhaps even block, change in the politics of Bangladesh. At the very least however, the mountaineers are to be commended for providing us with the living embodiment of Antonio Gramsci's aphorism - 'Pessimism of the intelligence, optimism of the will’.

\section{References}

Ahmed, N. (2013). 'The poetics of nationalism: Cultural resistance and poetry in East Pakistan/Bangladesh, 1952-71’. Journal of Postcolonial Writing, 50 (3), 256-268.

Bairner, A. (2001) Sport, Nationalism, and Globalization: European and North American Perspectives. Albany, NY: SUNY Press.

Bairner, A. (2004). 'Sports and nationalism'. In G. H. Herb and D.H. Kaplan (Eds.), Nations and Nationalism. A Global Historical Overview, Volume 3 1945-1989. ABC-CLIO, Santa Barbara, California, 2008,

Bandyopadhyay, K. (2013). Cricket as a nationalist obsession: ICC World Cup 2011 and Bangladesh as a host nation'. Sport in Society, 16 (1), 19-32.

Bartlett, P. (2013). 'Is Mountaineering a Sport?’ Royal Institute of Philosophy Supplement, 73: 145-157.

Cronin, M. (1999) Sport and Nationalism in Ireland. Gaelic Games, Soccer and Irish Identity since 1884, Dublin: Four Courts Press.

Dasgupta, S. (2007). 'Bangladesh Cricket: Scoring on Passion, but Little Else'. Sport in Society, 10 (1), 162-181. 
Dimeo, P. (2001). Football and Politics in Bengal: Colonialism, Nationalism and Communalism. Soccer and Society, 2 (2), 57-74.

Hossain, I. and Khan, M. H. (2006). 'The Rift Within An Imagined Community:

Understanding Nationalism(s) in Bangladesh’. Asian Journal of Social Science, 34 (2), 324339.

Moniruzzaman, M. 2009. 'Party Politics and Political Violence in Bangladesh: Issues, Manifestation and Consequences’. South Asian Survey, 16 (1), 81-99.

Porter, D. and Smith, A. Eds. (2004). Sport and National Identity in the Post-War World. London: Routledge.

Rowe, D. (2003) Sport and the Repudiation of the Global, International Review for the Sociology of Sport, 38 (3): 281-293.

\footnotetext{
' Professor of Sport and Social Theory, Loughborough University
} 